\title{
Do you say
}

\section{bonjour buenos días buon giorno guten Tag お早うございます。}

\section{before you say good morning?}

7 the strangest thing about 1 English is that it is used by more people as a second language than as a first. English is the language that allows us to communicate with one another across national borders.

Most doctors and biomedical scientists read English, even though it is not their native language. They also need to speak English and to understand others speaking English. This is more difficult because written English and spoken English are quite different. English Audio Reviews is an original method of language training designed by language experts and biomedical scientists to help you speak and understand spoken English with greater ease and confidence, within the context of your profession.

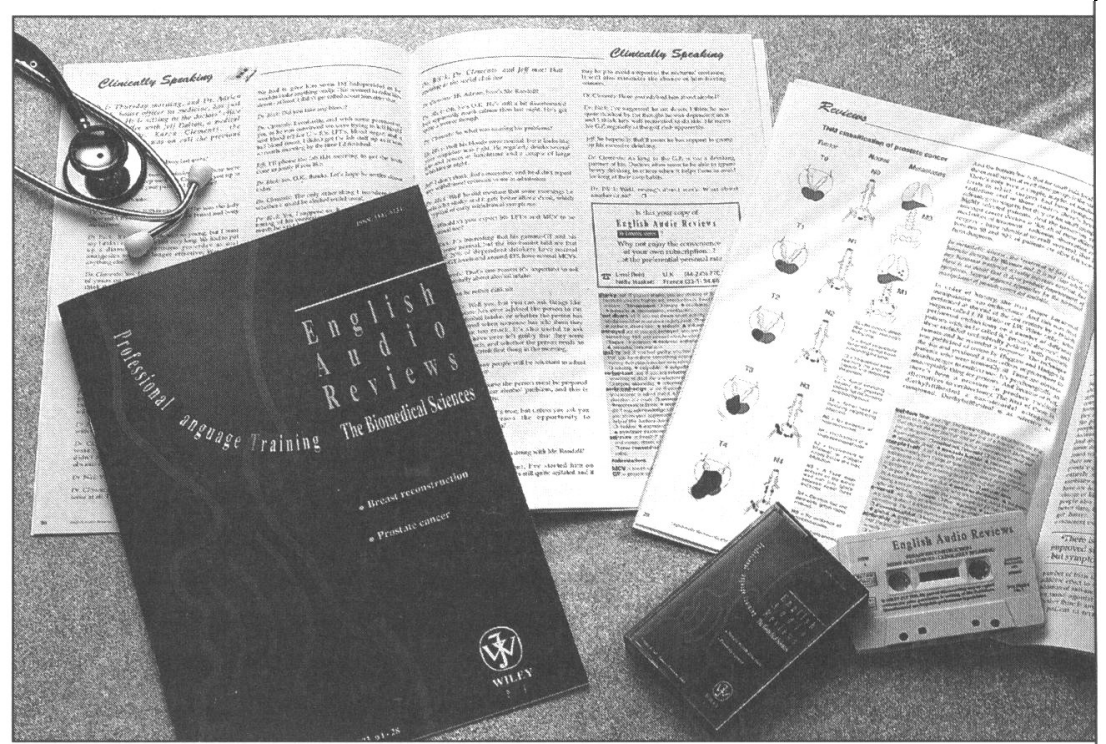

Every two months, a 60-minute cassette brings you interviews with leading specialists speaking on a broad range of topical subjects. Each cassette comes with a journal that has a full transcript of the cassette with explanations (in French, German, Italian, Spanish, Portuguese, and Japanese), of words and phrases that you might find difficult as a non-native speaker.

But E.A.R. does much more. You will also hear news items and clinical case histories. A section on everyday English highlights common expressions and idioms that are such an important part of the English language. There are also sections on pronunciation and exercises.

Biomedical scientists around the world are improving their English communication skills with English Audio Reviews. We believe you can too.

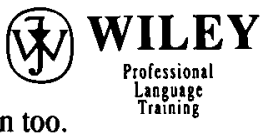

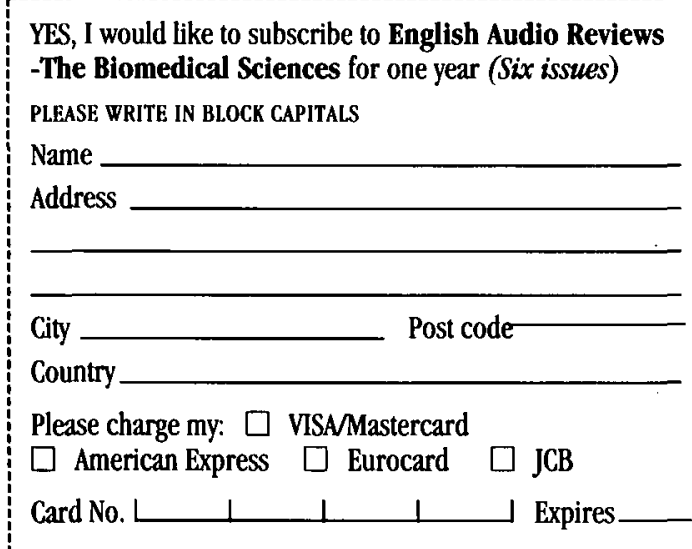

$\square$ Check enclosed Date Signature

Subscribers in Europe please return to: WILEY PLT/Wiley Europe BP 36, 95380 Louvres, FRANCE Personal rate 810 French francs/Institutional rate $1125 \mathrm{FF}$ Tel: +33134.68 .92 .50 Fax: +33134.72 .30 .50$

Subscribers outside Europe please return to: WILEY PLT/Department LR Baffins Lane, Chichester, West Sussex P019 1UD, UK Personal rate US\$165/Institutional rate US\$225 Tel: +44 (243) 770326 Fax: +44 (243) 539132 


\section{Progress in Photovoltaics Research and Applications}

\section{MANAGING EDITOR}

Paul A. Lynn

Progress in Photovoltaics

PO Box 878

Bristol

BS99 5LB

UK

\section{CONSULTANT \\ EDITORS}

Werner H. Bloss

University of Stuttgart

Germany

Martin A. Green

University of New South Wales

Australia

Joseph J. Loferski

Brown University

Rhode Island

USA

Tadashi Saitoh

Tokyo Institute of

Agriculture and Technology

Japan

\section{AIMS AND SCOPE}

The Journal aims to be the principal international focus for reporting progress across the whole range of Photovoltaics, right through from research and advanced development to practical implementation, field testing, economics and environmental aspects.

The Editors, recognising the different skills and challenges of these various areas, allocate papers and articles to three separate sections entitled 'Research', 'Applications', and 'Broader Perspectives', with appropriate refereeing criteria in each case.

The wide scope of the journal is intended to appeal to all professionals and practitioners in academic and research institutions, industrial companies, electric utilities, government agencies, and user organisations who need to keep informed about progress in this field of rapid current development. A special feature will be the regular publication of Solar Cell Efficiency Tables giving recent advances with the various cell technologies. Papers are encouraged on a variety of topics and applications:

Solar Cell and Solar Energy Research and Development

* Materials * Performance * Modelling * Fabrication * Industrial-scale Production * Solar Energy Characteristics and Statistics

Practical Implementation

* Stand-alone and Central-station Plant * Systems for Rural Development

* Concentration and Tracking * Utility Interconnection Criteria * System Design, Development and Commissioning * Space Systems and Nuclear Radiation * Field Testing * Performance Monitoring * Reliability

Economic and Environmental Aspects

* PV Economics * Market Applications Including Consumer Products

* Environmental, Social and Political Aspects * Safety * National PV

Programs * International Cooperation * Education and Training

The Editors will also include review articles, focus on industries, commissioned features, short communications, accelerated publication of research results, conference updates and professional activities.

\section{SUBSCRIPTION DETAILS}

ISSN: 10627995 Volume 1 (1993) Quarterly $\$ 195.00$

Personal subscribers are invited to subscribe at a specially reduced rate of $\$ 95.00$. Personal subscriptions must be paid out of personal funds and mailed to a private address.

For full subscription details and/or a free sample copy please write to either address:

Journals Subscription Department, John Wiley \& Sons Ltd, Baffins Lane, Chichester, West Sussex, PO19 1UD, England

Subscription Dept. C, John Wiley \& Sons Inc, 605 Third Avenue, New York, NY 10158, USA 


\section{INTERNATIONAL JOURNAL OF ENERGY RESEARCH}

\section{EDITOR}

\author{
J.T. McMullan \\ Dir, Centre for Energy Research \\ University of Ulster \\ Cromore Road, Coleraine \\ BT52 1SA, Northern Ireland \\ UK
}

\section{DEPUTY EDITOR}

\author{
D.E. Claridge \\ Dept of Mechanical Engineering \\ Energy Systems Laboratory \\ Texas A\&M University \\ College Station, TX 77843-3123 \\ USA
}

\section{AIMS AND SCOPE}

The area of Energy research and development is faced with several obstacles. It is an important and rapidly expanding field at a time of severe financial restraint. Its rapid expansion has meant a fragmentation of the literature and severe communication difficulties between workers. Frequently work of high utility and calibre receives less attention than its due purely because it does not reach a wide enough audience, either through the specific circulation of the journals used, or because there exists no suitable vehicle - particularly in the case of scientific and technological research. The International Journal of Energy Research aims to satisfy this need and provide an interdisciplinary platform for the results of energy research without the constraints imposed by aiming at a restricted audience.

The subject matter of the journal is concerned with the development and exploitation of both traditional and new fuels and other sources of energy, and an interdisciplinary approach to this interdisciplinary subject is encouraged. Areas of interest constantly change however. Papers have been published in the following areas: solar, nuclear, heat pumps, buildings, wavepower, transport, industrial, storage, wind, conservation, synthetic fuels, district heating to mention only a few. The editors do not wish to restrict the areas of energy research suitable for publication, but would suggest some guidelines. Submitted material should report on original work, which may be either in the area of scientific or technological development, or in the equally important area of feasibility, whether economic, environmental or technological. It is hoped that in all cases emphasis will be placed on some aspect of a particular field or group of energy possibilities: and that the discussions of feasibility and possible strategy should be aimed at a specific target rather than at a generalized concept of 'energy policy'. With this proviso, no material should be regarded inadmissible on grounds of subject matter alone.

The journal carries reviews on important development areas and these may either be invited by the editors or submitted in the normal way. Contributions may be either normal 'full length' papers or 'short communications'. Letters and book reviews are regular features and a conference diary is carried in each issue. Conference details to be included should be sent to the Editor.

\section{SUBSCRIPTION DETAILS}

\section{ISSN: $0363907 \mathrm{X}$ Volume 17 (1993) 9 Issues $\$ 950.00$}

Personal subscribers are entitled to $25 \%$ discount. Personal subscriptions must be paid out of personal funds and mailed to a private address.

For full subscription details and/or a free sample copy please write to either address:

Journals Subscription Department, John Wiley \& Sons Ltd, Baffins Lane, Chichester, West Sussex, PO19 1UD, England

Subscription Dept. C, John Wiley \& Sons Inc, 605 Third Avenue, New York, NY 10158, USA 


\section{(W) JOHN WILEY \& SONS LIMITED WILEY JOURNAL AUTHOR PUBLISHING AGREEMENT}

John Wiley \& Sons, Ltd requires a grant of copyright from authors of articles contributed to our journals in order to effectively publish and distribute these journals worldwide. Therefore, we ask you to confirm your acceptance of the following terms by signing and returning this agreement to us:

1. The undersigned (individually or collectively the "Author") hereby assigns to John Wiley \& Sons, Ltd (the "Publisher") for the full term of copyright, the sole and exclusive rights in the whole copyright in and to the article entitled

(the "Article")

for initial publication in the journal entitled

(the "Journal"). This grant of

rights includes, but is not limited to, the rights to republish and use the Article and the material contained therein, throughout the world, in all languages and in all media of expression now known or later developed, and to license or permit others to do so.

2. The Publisher will not withhold permission for any reasonable request from the Author to use material from the Article in connection with any other work by the Author, except for inclusion of all or a substantial part of the Article in a competing publication, provided the material appears with an appropriate credit to the Publisher and to the Journal and with copyright notice as set forth in the Journal. Such permission must be obtained from the Publisher in writing and in advance.

3. If the Article was written by the Author in the course of employment, the employer shall sign this agreement in the space provided below.

4. Any proprietary rights other than copyright (e.g. patent rights) are retained by the Author or the employer, as applicable.

5. If the Author is a U.S. government employee and this Article was prepared as part of his/her official duties, the Article will constitute a "U.S. Government Work" not protected by copyright in the U.S., but protectable outside the U.S. In such case, this assignment applies only outside the U.S. (If applicable, please mark the appropriate box provided below.) Note: If at least one co-Author is not a government employee, it is not a U.S. Government Work and said co-Author should sign this agreement.

6. In case of work prepared under U.S. Government contract, if the contract so requires the U.S. Government may reproduce, royalty free, all or portions of the Article and may authorise others to do so, for official U.S. Government purposes only. (If applicable, please mark the appropriate box provided below and attach a copy of the relevant contract.)

7. The Author warrants that the Article is the Author's original work and has not been published before. If excerpts from copyrighted works or illustrations provided by others are included, the Author will obtain written permission from the copyright owners and show credit to the sources in the manuscript. The Author also warrants that he or she has the right to enter into this Agreement, the Article contains no libelous or unlawful statements, contains no instructions that may cause harm or injury, and does not violate the copyright or trademark, or infringe on the rights or the privacy of others; and that all statements in the Article asserted as fact are either true or are based upon reasonable research.

8. If the article was prepared jointly by more than one Author, the Author warrants that he or she has been authorised by all co-Authors to sign on their behalf.

9. If the Article is accepted, publication in the Journal is deemed to constitute consideration. In addition, the Publisher will furnish the Author with a number of free copies of the Article, in accordance with its current applicable policies. If the Article is rejected, this assignment is null and void.

AGREED:

(Author)

Date

Date

(Employer (if applicable))

U.S. Government Employee

U.S. Government Contract attached 

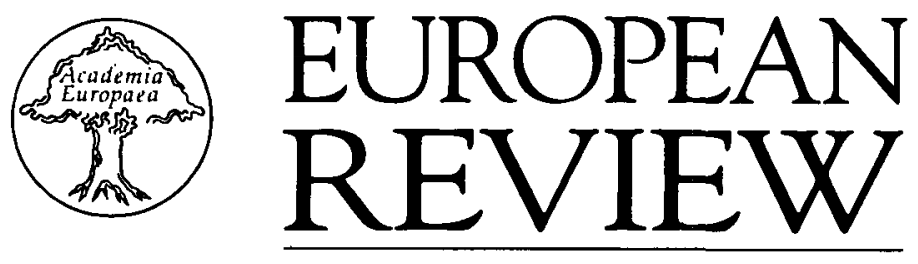

EDITOR-IN-CHIEF

Arnold Burgen

Department of Pharmacology

Tennis Court Road

University of Cambridge

Cambridge, CB2 10J

UK

\section{ASSOCIATE EDITORS}

Robert Cahn

Cambridge University, Department of Material Sciences and Metallurgy, Pembroke Street, Cambridge, CB2 10Z, UK

\section{Alexis Jacquemin}

16. Avenue Ptolémée, 1180 Brussels, Belgium

\section{Henri Korn}

Institut Pasteur, Laboratoire de Neurobiologie Cellulaire, Inserm U.261, 25 rue du Dr Roux, 75015 Paris, France

\section{Henk Wesseling}

Institute for the History of European Expansion, PO Box No 9515, 2300 RA Leiden,

The Netherlands

\section{Barbara Wright}

Trinity College, Department of French, Arts Building, Dublin, Ireland

\section{AIMS AND SCOPE}

The European Review is an Interdisciplinary Review Journal of the Academia Europaea. The contents reflect the broad range of disciplines included within the Academia, as well as its comprehensive European membership. The review will thus include articles covering a wide range of topics written so as to make them accessible to readers from other disciplines. Each issue will include a special section focused on a particular topic. The articles will be by authors mostly located in Europe and some will relate to specifically European questions.

The Editors welcome submissions to the Review.

\section{ACADEMIA EUROPAEA}

The Academia Europaea was established in 1988 to bring together scholars from across Europe, East and West, of all academic disciplines. It has already proved to be an admirable medium for tackling problems on a Europe wide basis and especially on an interdisciplinary basis-bringing together scholars from disciplines that would be unlikely to meet otherwise. It organizes symposia at annual meetings which move around Europe and which have covered subjects like the Rights of Minority Groups, the Image of Science, the Study of the Human Genome, Population Migration, and the Search for Meaning in Contemporary Life. It has also established study groups, the first of which has published its findings in a book on 'Schooling in Contemporary European Society', other studies are in progress on Psychological Problems of Youth in a Changing Europe, Energy Forecasting, Higher Education, and Risk Assessment in Relation to Atmospheric Changes.

It can be seen that the Academia Europaea has a wide perspective and this is reflected in its new journal the European Review.

The Academia is an independent organization based in London.

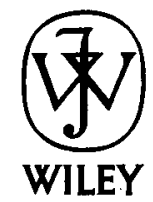

Chichester, New York, Brisbane, Toronto, Singapore

EURREK 1 1-392 (1993) ISSN 1062-7987 


\section{NOTES FOR CONTRIBUTORS}

1. The original and two copies of a manuscript submitted for publication should be sent to the Editor, Sir Arnold Burgen, Department of Pharmacology, Tennis Court Road, Cambridge, CB2 1QJ, UK. The Author's full postal address, as well as telephone, telex and fax numbers where available, should appear on the manuscript.

2. Only original papers, not published elsewhere, will be accepted, and the copyright should be assigned to the Publisher by filling in the Publishing Agreement form which the Editor will send to the prospective author, and which may also be found reproduced in each volume of the Journal.

3. The language of the Review is English.

4. Manuscripts are to be typed double-spaced, with wide top and side margins, on one side of the paper only. Illustrations are to be submitted with the manuscript on separate sheets. Authors are advised to keep one copy of their manuscript for reference. A summary of 100-150 words should be provided.

5. The title should be brief. It should appear on a separate sheet, with the Author's name typed on the line below the title.

6. The papers should be subdivided into sections and, if necessary, subsections.

7. Mathematical symbols may be hand-written or typed: Greek letters and unusual signs should be identified separately in the margin. Distinction should be made between letter $O$ and zero; between letter $I$ and number 1 and prime. All abbreviations should be preceded the first time they appear by the full name. Boldface, spacing, and italics for emphasis are to be avoided; the latter are to be used, though, for words taken over from other languages and not integrated in the language of the text.

8. Figures and tables are to be numbered consecutively and placed on separate sheets, with their place in the running text indicated therein.

9. Half-tone illustrations are to be restricted in number to the minimum necessary. Good glossy bromide prints should accompany the manuscript; they should not be attached to manuscript pages.

10. Original outline drawings (not photocopies) should be submitted suitable for immediate reproduction. Drawings should be of about twice the final size; the lettering must be clear and large enough for proportionate reduction. Figure legends should be typed on a separate sheet and placed at the end of the manuscript.

11. Footnotes are to be held to a minimum; parentheses in the text are to be preferred. Footnotes are not to be used for bibliographical references.

12. References to published literature should be quoted in the text by superior numbers and grouped together at the end of the paper in numerical order. Journal references should be arranged thus:

1. F. Fukuyama, 'The End of History', The National Interest, 16, 3-19 (1989).

Book references should be as follows:

2. J. Cadwell, Theory of Fertility Decline, Academic Press, London, 1982.

13. For many articles submitted to the publication, it may be more useful to provide a short bibliography under the heading 'Further Reading'.

14. No manuscript or illustration will be returned following publication unless a request for return is made at the time when the manuscript is submitted.

15. Page proofs are sent to authors for the correction of printers' errors; alterations of the text will not be accepted. Corrected proofs should be returned to the Publisher within 48 hours of receipt.

16. Twenty-five offprints of the paper and one copy of the Journal issue in which it appears will be provided to the Author free of charge. Additional copies of the article and the Journal may be purchased from the Publisher on an offprint order form supplied with the proofs.

17. It is the Author's responsibility to obtain written permission to quote material which has appeared in another publication.

18. Authors should submit a brief autobiography of approximately 75-100 words for publication in the Journal.

\section{COPYING OF ARTICLES}

The code and the copyright notice appearing at the bottom of the first page of an article in this journal indicates the copyright owner's consent that copies of the article may be made for personal or internal use, or for the personal or internal use of specific clients, on the condition that the copier pay for copying beyond that permitted by Sections 107 or 108 of the U.S. Copyright Law. The per-copy fee for each article appears after the dollar sign, and is to be paid through the Copyright Clearance Center Inc. The consent does not extend to other kinds of copying such as copying for general distribution, for advertising or promotional purposes, for creating new collective works, or for resale. Such permission requests, or other inquiries should be addressed to the publisher. 


\section{Contents}

VOLUME 1 NUMBER 4

OCTOBER 1993

The Present State and Future of Science in Russia

S. KAPITZA.

Geography and the International Global Change Programmes

W. MANSHARD

Museums of Natural History-Do We Need their Collections in the Time of Molecular

Biology?

S. MATHIASSON.

The Ecological Economics of the Baltic Sea

T. ŻYLICZ

FOCUS-Nations, States and Human Rights

Nations, States and Human Rights

A. BURGEN .

Nationalism and Politics in Eastern Europe

E. GELLNER.

Nation and State in East Central Europe

D. KOSÁRY.

State Building and Nation Building

J. J. LINZ .

Collective Minority Rights and Problems in their Legal Protection: the Example of Yugoslavia T. VARADY.

State, State-nation, Cultural Nation

F. GLATZ

Author Index.

Contents of Volume 1

iii 